\title{
Digital Transformation of Innovative Business Processes on Railway Transport
}

\author{
Viktoria Ovchynnikova ${ }^{1 *}$, Anna Kuzmenko², Tetyana Yusupova ${ }^{1}$, Vladislava Toropova ${ }^{3}$, \\ and Nadia Gontar ${ }^{1}$ \\ ${ }^{1}$ Ukrainian State University of Railway Transport, Economy and Management of Industrial and \\ Commerce Business Department, Feyerbakh sq. 7, 61050 Kharkiv, Ukraine \\ ${ }^{2}$ Kharkiv Institute of Finance of Kyiv National University of Trade and Economics, Management \\ Department, Pletnevsky prov. 5, 61003 Kharkiv, Ukraine \\ ${ }^{3}$ Simon Kuznets Kharkiv National University of Economics, Management and Marketing \\ Department, Nauky av. 9-a, 61166 Kharkiv, Ukraine
}

\begin{abstract}
The article finds that acceleration of the pace of global highintellectual development causes the digital transformation of innovative business processes in the Ukrainian railway transport, and consequently, the continuous improvement of intellectual information systems and technologies of management of innovative processes. The study of the existing models of the innovation process enabled to distinguish its sixth type of "model of digital networks and artificial intelligence". The main feature of this stage of the development of the innovation process is the formation of a single digital platform (innovation portal), which will allow to make transparent the basic business procedures and to form Big Data with the ability to optimize the main innovative business processes. It is proved that a new approach to innovative business processes should include the formation of an intellectual information platform for innovative management which should become a key link to support innovative business processes in the industry. An integrated data bank (Big Data) and situational control centers should also be created as tools for promoting the process of making innovative decisions. As the coordinating situation centers of innovation activity, it is advisable to distinguish between "Investments", "Innovation", "Personal”, "Transport Logistic”.
\end{abstract}

\section{Problem statement and its connection with scientific or practical tasks}

At present, one of the acute and urgent problems is the problem of effective organization of innovative activity of railway transport and efficient use of its production potential in the transition to the digital economy, because the development of the latter forms the main trends in the development of transport and logistics business worldwide, including in Ukraine. The most significant among them are: globalization of transport and logistics business; active development of transnational Internet resources; rapprochement of

*Corresponding author: vikols75@ukr.net 
transport and logistics services providers and consumers; emergence of new distribution channels; change of consumption model: personification of the approach in the organization of transportation of goods and passengers, etc. Therefore, only knowledge-intensive, highperformance operational activities of railway transport can become the basis and the main condition for economic growth of the industry and the whole country in the digital economy.

\section{Analysis of recent research and publications}

The modern policy of management of innovative activity of railway transport should first of all be consider on transformation of the most innovative process. Regarding the current models of the innovation process, they do not meet the modern realities of the functioning of the world rail transport. They can be divided into five types:

- the first type of innovation process model (1950s - 1960s) is characterized as "a model that is pushed by technology (technology push-model), is a simple linear-sequential process with an emphasis on the crucial importance of research and development work and the attitude to the market only as a consumer of the results of technological activity of production" [1]. This type of model of the innovation process can meet the scientists: S. Ilyenkova [2], V. Grinev [3], V. Kardash [4], L. Vodachek and O. Vodachkova [5], T. Alimova [6];

- the second type of model of the innovation process (1960s and 1970s) scientific opinion defines this type of model as a "linear sequential model, but with an emphasis on the importance of the market, which needs to react to R\&D (need pull model)" [151]. This type of model can be seen in the works of J. Bradbury [6], H. Holstein [7], P. Doyle [8], Donald J. Margus [6];

- the third type of model of the innovation process (1970s and 1980s) called the "coupled type of model (coupling model), which is a combination of the models of the first and second type, with focus on communication of technological possibilities and capabilities with the needs of the market". A striking representative of this type is the chain model (chain link model) S. Kline - N. Rosenberg [9];

- the fourth type of innovation process model (1980s and 2010s) the innovation process is defined as "simultaneous, but not joint work of several groups of specialists from different structural divisions of the enterprise on one innovation". An example of the fourth type of model is the process of development of a new product of Nissan [1], as well as the "Japanese" model of innovation process [10];

- the fifth type of innovation process model (early 2010s until the present) is characterized as "strategic networking model and model of innovation and strategic networks, integration and networking" [1].

\section{Transformation of the innovation process in the digital economy}

The acceleration of the global high-intellectual development determines the digital transformation of innovative business processes in the railway transport of Ukraine, respectively, the constant improvement of intellectual and information systems and technologies of management of innovative processes. Digital transformation is a continuous process that undoubtedly carries a huge potential for improving the efficiency and development of the industry, as well as provides for fundamental changes in the conceptual provisions of innovative business processes. This allowed us to identify the sixth type of 
innovation process model (Fig. 1), namely, a model of digital networks and artificial intelligence.

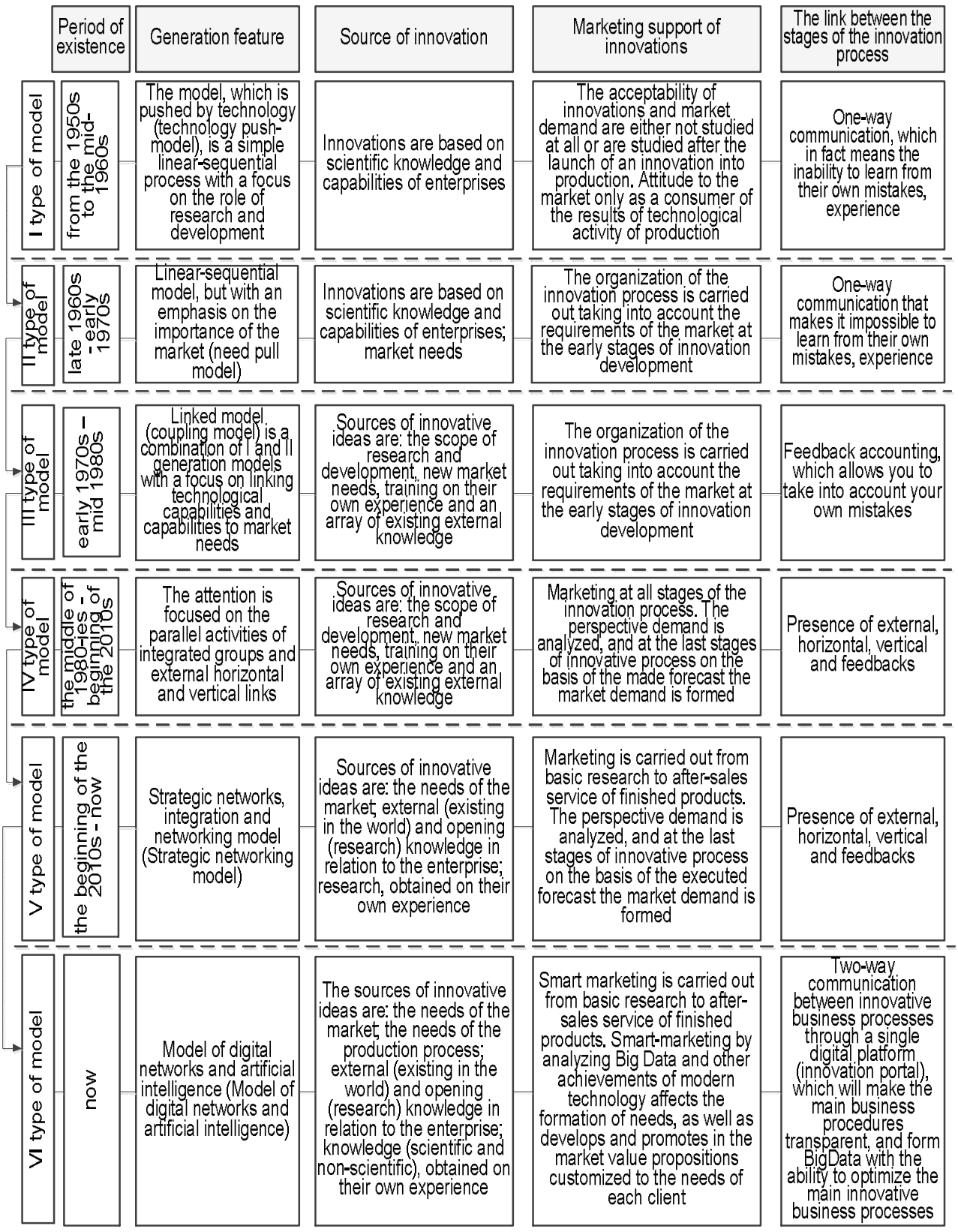

Fig. 1. The main characteristic features of the innovation process models.

The main feature of this stage of development of the innovation process is the formation of a single digital platform (innovation portal), which will make the main business procedures transparent, and form Big Data with the ability to optimize the main innovative business processes. At the same time, smart marketing is advisable to carry out from basic 
research to after-sales service of finished products, in addition, by analyzing Big Data and other achievements of modern technology to influence the formation of consumer needs, as well as to develop and promote in the market value propositions customized to the needs of each client.

\section{Integrated intellectual and information platform for innovative changes as an imperative factor of innovation in the digitalization of the economy}

A new approach to innovative business processes should provide for the formation of an integrated intellectual and information environment of interaction between branches of Ukrzaliznytsia JSC, because one of the important areas of strategic management of the enterprise is the process of making management decisions in modern conditions of formation of significant information flows and uncertainty of the environment is much more complicated. Therefore, now the management of railway transport should definitely form an intellectual and information platform for innovation management, which should become a key link in the future, which will support innovative business processes in the industry, because its feature is the concentration and reflection of information about the impact of each branch of Ukrzaliznytsia JSC on the processes of implementation of innovative changes in the railway industry.

The effectiveness of innovative processes in the railway industry largely depends on the quality of the formation of an integrated intellectual and information platform to ensure innovative changes in the railway industry [11-14], which, on the one hand, creates conditions for the introduction and use of leading intellectual and information systems and technologies for the development of branches of Ukrzaliznytsia JSC, and on the other $\square$ provides their strategic interaction within the virtual space. In this context, the definition of intellectual and information systems and technologies that will become the basis for the formation of such an integrated intellectual and information platform is of strategic importance. The most common of them include the platform DSS (Decision Support System) - a class of automated information systems that help to collect the necessary information for decision-making and choose the best solution to achieve a specific goal. Structurally, the DSS system consists of [15]:

1. Data Warehouse - information platform DSS. Data warehouses allow you to integrate information that reflects different perspectives on the same subject area.

2. Business Intelligence Tools (business intelligence tools) - software that enables users to observe and use large amounts of complex data. The main components of the intelligent information system DSS is [16, 17]: OLAP (OnLine Analytical Processing); Data Mining; COMFAR; BEST (Business Environment Strategic Toolkit); FIT (Financial Improvement Toolkit), etc.

Given the above, it is also important to create an integrated data Bank (Big Data) and situational management centers as tools to facilitate the process of innovative decisionmaking based on a comprehensive analysis of the factors influencing the subjects of the relevant system on the process of implementing strategic initiatives of highly intelligent development of railway transport through the use of the necessary intellectual and information systems and technologies. As coordinating situation centers of innovation activity, it is advisable to distinguish the following: "Investments", "Innovation", "Personal", and "Transport Logistic".

Intellectual and information platform of innovative development of subjects of investment activity should be represented by intellectual and information systems and technologies that provide analytical processing of large volumes of information about 
financial subjects of innovative activity; automation of processes of financial and economic analysis of innovative projects; the use of information tools to support decision-making on the effectiveness of the implementation of priority innovative projects and the like. The processes of implementation of the relevant intellectual and information systems and technologies are controlled by the situation center of management "Investments".

Automation and improvement of intellectual and information support of processes of development of innovative products as the basis of innovative and technological renewal of railway infrastructure and rolling stock is implemented within the intellectual and information space of subjects of innovative activity, cooperate in the framework of the project. The introduction of intellectual and information technologies in this area will provide automation and mutual coordination of design and modeling of innovative products; automation of production and technological processes; management of supply processes of raw materials; automation of processes of adjustment and readjustment of equipment; improvement of relationships with suppliers and consumers; introduction of intelligent information systems to promote strategic management decisions in conditions of uncertainty and risk, and the like. Control of the processes of implementation and adaptation of intellectual and information systems and technologies of development of subjects of innovative activity takes place within the framework of the situation center of management "Innovation".

An important stage in the implementation of intelligent information systems is the training of modern specialists in the field of intelligent transport systems, which includes the study of system-wide features of intelligent transport systems, as well as the analysis and formal description of the processes of creating such automated systems that are "able to learn" (generate new knowledge in the form of mathematical models, control patterns), "classify" (automatically group objects, actions, control signals), adapt to changing conditions and parameters of the operating environment - "adapt". The solution of these problems is not possible without the formation of future specialists in the field of intelligent transport systems of system thinking, knowledge and skills of the system approach and system analysis to solve complex organizational, technical and technological problems, as well as knowledge bases of certain methods and examples of the implementation of complex projects of the transport complex on the basis of global integrated information and communication technologies. Thus, the development and implementation of intelligent information systems and technologies is closely related to the adaptability and flexibility of railway personnel to strategic changes, which makes it important to ensure its intellectual development. Among the main intellectual and information systems that provide distance and multimedia training, it is advisable to highlight: Webinar, Comdi, Acrobat Connect Pro, Mirapolis, Virtual Room, eLearning Server, iMind, iWebinar, Moodle. Some of them have already become widespread among the specialized higher educational institutions of the country, providing the opportunity to obtain the necessary knowledge and skills on the job through the use of these intellectual and information systems and technologies. Implementation of the processes of intellectual development of the personnel is planned within the limits of the situational center of management "Personal".

A key element in the formation of an integrated intellectual and information environment of interaction between the branches of Ukrzaliznytsia JSC should be intellectual and information systems and technologies for the development of transport and logistics activities. In turn, the unified information space of Ukrzaliznytsia JSC should be provided with a set of existing unified automated control systems for freight and passenger transportation, infrastructure, traction, production and service. 


\section{References}

1. R. Rothwell, The Changing Nature of the Innovation Process, Technovation, (1993) http://technopark.al.ru/business/innovation.htm. Accessed 19 Apr 2019

2. S.D. Ilenkova, Innovatsionnyy menedzhment, Moscow, 327 (1997)

3. V.F. Grinev, Innovatsionnyy menedzhment, Kiev, 148 (2000)

4. V.Ya. Kardash, Tovarna innovatsiyna polityka, Kiev, 124 (1999)

5. L. Vodachec, O.Vodachkova, Strategicheskoye upravleniye innovatsiyami na predpriyatii, Moscow, 167 (1989)

6. V.N. Goncharov, E.V. Ivanova, Concept of strategic organization of innovative activity of enterprises, URL: www.maop.vorstu.ru/Gancharov.html. Accessed 07 May 2019

7. P. N. Zavlyn, A. K. Kazantsev, L. E. Mindeli, Innovatsionnyy menedzhment, Moscow, 173 (1998)

8. P. Doyle, Menedzhment: strategiya i taktika, St. Petersburg, 560 (1999)

9. E.O. Naumenko On the model of management of the innovative process of the enterprise in modern conditions, URL: http://ej.kubagro.ru/2006/04/pdf/03.pdf. Accessed 03 May 2019

10. F. Kodama, Emerging patterns of innovation sources of Japan's technological edge, Harvard Business School, 245 (1995)

11. V.L. Dykan, Bulletin of the Economy of Transport and Industry, 42, $144-149$ (2013)

12. V.O. Ovchynnikova, Stratehichne upravlinnya rozvytkom zaliznychnoho transportu Ukrayiny, Kharkiv, 427 (2017)

13. O.V. Dykan, Orhanizatsiyno-ekonomichnyy instrumentariy zabezpechennya konkurentospromozhnosti promyslovykh pidpryyemstv zaliznychnoho transportu, Kharkiv, 443 (2016)

14. I.V. Tokmakova, Zabezpechennya harmoniynoho rozvytku zaliznychnoho transportu Ukrayiny, Kharkiv, 403 (2015)

15. G.A. Mamaeva, The Age of Science, 13, 81-86 (2018)

16. Methods and systems for supporting decision making, http://iintellect.ru/articles/45/. Accessed 21 Apr 2019

17. Intelligent Information Systems in Management, https://rep.bntu.by/bitstream/handle/data/23986/\%D0\%A2..B8.pdf?sequence=11. Accessed 19 Apr 2019 